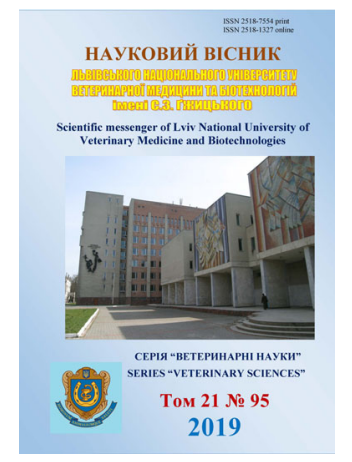

\section{Науковий вісник Яьвівського національного університету ветеринарної медицини та біотехнологій імені С.3. Гжицького. Серія: Ветеринарні науки}

\author{
Scientific Messenger of Lviv National University \\ of Veterinary Medicine and Biotechnologies. \\ Series: Veterinary sciences
}

ISSN 2518-7554 print ISSN 2518-1327 online doi: $10.32718 /$ nvlvet9528

http://nvlvet.com.ua

UDC 619:591.423:636.5:551.521

\title{
Morphology of trachea of mature chickens, grown under the conditions of radioactive contamination
}

\author{
L.P. Horalskyi ${ }^{1}$, I.M. Sokulskyi ${ }^{1}$, N.V. Demus ${ }^{2}$, O.K. Levchuk ${ }^{1}$ \\ ${ }^{1}$ Zhytomyr National Agroecological University, Zhytomyr, Ukraine \\ ${ }^{2}$ Stepan Gzhytskyj National University of Veterinary Medicine and Biotechnologies Lviv, Ukraine
}

\section{Article info}

Received 24.09.2019

Received in revised form 24.10.2019

Accepted 25.10.2019

Zhytomyr National Agroecological University, Staryj Boulevard, 7. Zhytomyr, 10002, Ukraine Tel.: +38-097 4857320 E-mail: sokulskiy_1979@ukr.net

Stepan Gzhytskyi National University of Veterinary Medicine and Biotechnologies Lviv, Pekarska Str., 50, Lviv, 79010, Ukraine.
Horalskyi, L.P., Sokulskyi, I.M., Demus, N.V., \& Levchuk, O.K. (2019). Morphology of trachea of mature chickens, grown under the conditions of radioactive contamination. Scientific Messenger of Lviv National University of Veterinary Medicine and Biotechnologies. Series: Veterinary sciences, 21(95), 150-155. doi: $10.32718 /$ nvlvet9528

The features of macro- and microscopic structure and morphometric parameters of the trachea of chickens of the Black Moscow breed of 180 days of age grown in conditionally pure and II zone of radioactive contamination are presented in the work using radiological, morphological, morphometric and statistical methods of research. It has been found that the presence of chickens in radioactively contaminated territories, feeding them with locally-sourced food, has an adverse effect on the respiratory organs, including the trachea. According to the results of radiological research, the increase of gamma background was established in the territory where the experimental part of the research was conducted. Thus, according to our observations, the specific power of the exposure dose of gamma rays for cesium-137 in the territory where the experimental animals were kept was almost in 3-3.5 times higher than this indicator for the relatively pure radioactive contamination of the territory. The specific activity of the diet for cesium-137 in chickens of 180 days of the experimental group was almost 8.5 times higher than in the control group of animals and was 13.4-16.0 Bq/ $/ \mathrm{kg}$, compared with the control (1.64-1.82 Bq/ $\mathrm{kg})$, indicating the cumulative capacity of this isotope. According to our research, the trachea of chickens of the experimental group has a pale pink color and is built of cartilage rings (110-120 units), which have a rounded shape. Its wall is formed by the mucous and fibrous cartilage and adventitia. The mucous membrane has a folded structure and is lined with multilayered ciliated epithelium and contains glands. Four types of cells are well differentiated into the epithelium: basal, ciliated, endocrine, and goblet. The fibrous cartilage sheath is formed by tracheal cartilages, which are interconnected by a dense fibrous connective tissue. The histoarchitectonics of the trachea of chickens reared in the second zone of radioactive contamination is similar to that of chickens in the control group. However, our morphometric studies noted that the animals of the experimental group increased the size of the terminal parts of the tracheal glands, thickened connective tissue capsules of the lymph nodes. The absolute body mass of the chickens of the experimental group, compared with the control group, tends to decrease and is respectively $2.96 \pm 0.19 \mathrm{~g}$, while the relative weight of the organ significantly $(P \leq 0.001)$ decreases to $0.284 \pm 0.027 \%$. In addition, for 180-day-old chickens that were constantly under radioactive contamination, the thickness of the mucous, fibrous, cartilage, and adventitious membranes tended to decrease compared to chickens from the conditionally clear area for radioactive contamination.

Key words: radioactive contamination, chickens, trachea, histostructure, macro-microscopic structure, mucous membrane, adventitia, absolute mass, relative mass.

\section{Морфологія трахеї статевозрілих курей, вирощених в умовах радіоактивного забруднення}

\author{
Л.П. Горальський ${ }^{1}$ І.М. Сокульський ${ }^{1}$, Н.В. Демус ${ }^{2}$, О.К. Левчук ${ }^{1}$
}


${ }^{1}$ Житомирський національний агроекологічний університет, м. Житомир, Україна

${ }^{2}$ Львівський національний університет ветеринарної медицини та біотехнологій імені С.3. Гжсицкого, м. Львів, Україна

У роботі за використання радіологічних, морфологічних, морфометричних та статистичних методів досліджень викладено особливості макро- та мікроскопічної будови та морфометричні показники трахеї курей Чорної московської породи 180 -добового віку, вирощених в умовно чистій та II зоні радіоактивного забруднення. 3'ясовано, шуо перебування курей на радіоактивно забруднених територіях, годівля їх кормами місцевого походження піддає організм тварин негативному впливу на органи дихання, в тому числі трахеї. За результатами радіологічного дослідження встановлено підвищення гамма-фону на території, де проводилась експериментальна частина досліду. Так, згідно з нашими спостереженнями, питома потужність експозиційної дози гаммавипромінювань за иезієм-137 територї, де утримувались дослідні тварини, майже в 3-3,5 разу перевишувала ией показник на відносно чистій щодо радіоактивного забруднення території. Питома активність раціону за цезієм-137 для курей 180 -добового віку дослідної групи майже у 8,5 разу перевищувала аналогічний показник в контрольній групі тварин і становила 13,4-16,0 Бк/кг порівняно з контролем (1,64-1,82 Бк/кг), що вказує на кумулятивну здатність иььоо ізотопу. За нашими дослідженнями, трахея курей дослідної групи має блідо-рожевий колір і побудована із хрящьових кілецьь (110-120 од.), шчо мають округлу форму. Її стінка утворена слизовою і волокнисто-хрящовою оболонками та адвентицією. Слизова оболонка має складчасту будову і вистелена багаторядним війчастим епітелісм і містить залози. В епітелію добре диференціюються чотири види клітин: базальні, війчасті, ендокринні та келихоподібні. Волокнисто-хрящова оболонка утворена трахейними хрящами, які між собою з'єднані щільною волокнистою сполучною тканиною. Гістоархітектоніка трахеї курей, вирощених у другій зоні радіоактивного забруднення, подібна до такої у курей контрольної групи. Проте намими морфометричними дослідженнями відмічено, шңо у тварин дослідної групи збільшуються розміри кінцевих відділів трахейних залоз, потовщуються сполучнотканинні капсули лімфатичних вузликів. Абсолютна маса органа курей досліднӧ групи, порівняно з контрольною групою, має тенденцію до зменшення $і$ становить відповідно $2,96 \pm 0,19$ 2, тимчасом як відносна маса органа достовірно $(P \leq 0,001)$ зменшується і дорівнює 0,284 $\pm 0,027 \%$ Крім того, у 180добових курей, які постійно перебували в умовах радіоактивного забруднення, показники товщини слизової, волокнисто-хрящової та адвентиційної оболонок, порівняно із курми з умовно чистої зони щцодо радіоактивного забруднення, мають тенденцію до зменшення.

Ключові слова: радіоактивне забруднення, кури, трахея, гістоструктура, макро- мікроскопічна будова, слизова оболонка, адвентиція, абсолютна маса, відносна маса.

\section{Вступ}

Екологічною проблемою довкілля є високий рівень радіоактивного забруднення біосфери, що негативно впливає на життєдіяльність (ріст, розвиток, функціонування органів і систем організму) людей і тварин (Dubovyi, 2014).

Радіоактивне забруднення навколишнього середовища досягло глобальних катастрофічних масштабів (Lypska et al., 2014). Найтяжчими для екосистем світу, а особливо для здоров'я людини та тварин, стали екологічні наслідки найбільшої техногенної катастрофи на Чорнобильській атомній електростанції (Hudkov \& Kashparov, 2012).

Викид радіоактивних речовин у результаті Чорнобильської аварії відбувається протягом достатньо тривалого часу з різних частин активної зони (Romanchuk, 2012).

Житомирська область після катастрофи на Чорнобильській АЕС постраждала найбільше, 56,7\% ii загальної площі забруднено радіонуклідами, що становить близько 16,1 тис. км² (Tykhenko, 2012).

Останніми роками проведено великий обсяг цінних вітчизняних та закордонних радіоекологічних досліджень, опубліковано чимало праць з цієї проблеми (Kvacheva, 2002; Horalskyi et al., 2004; Khomenko, 2008; Dunaievska, 2013). Однак тривала дія низьких доз радіації, особливо іiі кумулятивний ефект на організм людей i тварин потребує подальшого дослідження.

Патологія органів дихання, згідно $з$ дослідженнями, проведеними після аварії на чорнобильській АЕС, займає одне 3 перших місць у структурі хвороб, пов'язаних із радіаційним навантаженням на організм (Dieltsova et al., 1998).

Вплив іонізуючої радіації на гістоархітектоніку органів дихання залежить від функціонального стану організму, тому зміни в органах під впливом радіоактивного випромінювання не мають чіткої специфічності (Antoniuk et al., 2002).

Радіочутливість організмів різних видів проявляється у здатності їх реагувати у відповідь на подразнення, що зумовлено поглинутою енергією іонізуючого випромінювання. Відомо, що дози випромінювання, які призводять до захворювання або ж загибелі різних організмів, неоднакові. 3'ясовано, що органи та тканини мають різну радіочутливість; свого роду індикатором радіоактивного впливу є ураження гомеостатичної, імунної, ендокринної систем, гонад, органів зору тощо. Зазвичай існує взаємозв'язок між рівнем розвитку організму й чутливістю до іонізуючого опромінення. Навіть в одному організмі різні тканини i клітини значно різняться щодо радіочутливості. Ефект дії радіації залежить ще й від того, які саме тканини і органи зазнали опромінення. Органи і тканини за їхньою чутливістю до дії радіації уражаються в такому порядку. Найбільш чутливі: яєчники, гіпофіз, надниркові залози, кров, щитоподібна залоза, потім - травний канал, кістки, м'язова тканина, шкіра, печінка й легені (Horalskyi et al., 2004). Взагалі біологічна ефективність опромінення і радіаційна загибель клітин прямо залежать від швидкості процесів обміну, що відбуваються в них, кількості внутрішньоклітинних структур, фази та інтенсивності клітинного циклу на певному етапі (Kvacheva, 2002). Відповідно прояви морфологічних змін в одному й тому ж органі можуть бути різними (Horalskyi er al., 2012). I нарешті, у всіх 
тварин, включаючи людину, велику роль у зміні радіочутливості можуть відігравати генетичні фактори та гормональний баланс. При цьому вплив іонізуючої радіації на гістоархітектоніку органів дихання, в тому числі і трахеї, залежить від функціонального стану організму, тому їх зміни під впливом радіоактивного випромінювання не мають чіткої специфічності.

За літературними даними, організм не всіх тварин, які вирощені на забрудненій радіонуклідами теритоpiї, уражається однаково, що залежить, напевно, від виду, віку, статі й навіть індивідуальної реактивності організму (Khomenko, 2008; Horalskyi et al., 2012; Troianchuk, 2012).

Саме тому вивчення гістоархітектоніки трахеї тварин є актуальним у вивченні впливу іонізуючого випромінювання на структуру та морфометричні показники.

Мета і завдання дослідження. Метою досліджень було з'ясувати вплив низьких доз радіації на гістоструктуру трахеї статевозрілих курей. Для досягнення поставленої мети були поставлені такі завдання: встановити рівень забрудненості радіонуклідами територій, приміщень, де вилупились і постійно утримувались дослідні та контрольні тварини; з'ясувати особливості мікроскопічної будови трахеї у курей 180добового віку, вирощених в умовно чистій зоні щодо радіоактивного забруднення та II зоні щодо радіоактивного забруднення.

\section{Матеріал і методи досліджень}

Дослідження проводили на кафедрі анатомії і гістології факультету ветеринарної медицини Житомирського національного агроекологічного університету.

Дослідження виконано у рамках науково-дослідної роботи кафедри анатомії і гістології "Розвиток, морфологія та гістохімія органів тварин у нормі та при патології, (номер державної реєстрації № 0113V000900).

Об'єктом дослідження були кури Чорної московської породи 180-добового віку (10 контрольних і 10 дослідних). Контрольні групи тварин вирощувались у м. Житомир і (умовно чиста зона щодо радіаційного опромінення), де природний радіаційний фон становив до 27 кБк/м². Дослідні тварини вирощувались у Народицькому районі Житомирської області. Згідно з Постановою Кабінету Міністрів України за № 106 від 23 липня 1991 року ця територія належить до другої зони радіоактивного забруднення (зона безумовного (обов'язкового) відселення), де щільність радіонуклідного забруднення сільськогосподарських угідь становить 5-15 Кі/км² за цезієм-137 (185-555 кБк/м²).

Утримання тварин та маніпуляції проводилися відповідно до основних правил лабораторної практики GLP (1981), положень “Загальних етичних принципів експериментів на тваринах”, ухвалених Першим Національним конгресом з біоетики (Київ, 2001 р.) та вимог до "Правил проведення робіт з використанням експериментальних тварин”, затверджених наказом
Міністерства охорони здоров’я, № 281, від 01 листопада 2000 р. “Про заходи щодо подальшого удосконалення організаційних форм роботи 3 використанням експериментальних тварин”.

В роботі використовувались радіологічні, морфологічні, морфометричні та статистичні методи досліджень (Horalskyi et al., 2015).

Для морфологічного дослідження відбирали трахеї у контрольних і дослідних тварин, визначали їх абсолютну та відносну масу, а також довжину й ширину.

Для гістологічного дослідження відразу після декапітації тварин відбирали шматочки матеріалу товщиною не більше ніж 5 мм. Матеріал фіксували в 10\% розчині нейтрального формаліну та рідині Карнуа 3 подальшою швидкою заливкою в парафін за схемами, запропонованими у посібниках Л.П. Горальського., В.T. Хомича, О. I Кононського (Horalskyi et al., 2015). Зрізи виготовляли на санному мікротомі МC-2 товщиною до 10 мкм. Фарбування гістозрізів проводили гематоксиліном та еозином, а також за Ван-Гізоном.

Мікрофотографування гістологічних препаратів здійснювали за допомогою мікроскопа Micros MC-50 i вмонтованої у нього відеокамери CAM V200, підключеної до персонального комп'ютера, а також мікроскопа МБС-10 із цифровою фотокамерою “Canon”.

\section{Результати та їх обговорення}

Згідно з радіологічними дослідженнями у II зоні радіоактивного опромінення середня потужність експозиційної дози гамма-випромінювання втричі перевищувала цей показник в умовно чистій зоні. При цьому питома активність кормів раціону курей 180добового віку дослідної групи за цезієм-137 становила 13,4-16,0 Бк/кг, що достовірно у 8-9 разів більше порівняно з контролем (1,64-1,82 Бк/кг).

Питома активність за цезієм-137 трахеї курей 180добового віку була вищою на 5\% (13,8 \pm 0,13 Бк/кг) за аналогічний показник у курей контрольної групи $(13,1 \pm 0,1$ Бк/кг), що вказує на кумулятивну здатність цього ізотопу.

Трахея курей розташована в ділянці шиї і передньої частини грудо-черевної порожнини. В порожнині тіла вона у вигляді біфуркації поділяється на два бронхи, які вступають у легені (рис. 1). Це порожниста, достатньо довга трубка. Жорсткість і гнучкість їі конструкції зумовлені наявністю у стінці різної кількості хрящових кілець, з'єднаних одне 3 одним щільною сполучною тканиною з високим вмістом еластичних волокон. Вона на поперечному розрізі має округлу форму i на своєму шляху часто утворює незначні петлі та звивини, тому іiі довжина дещо перевищує довжину шиї. У курей нараховують до 110-120 хрящових кілець, що мають округлу форму. На краніальному і каудальному краях кожного трахейного хряща містяться кутові вирізки. У середніх ділянках трахейні хрящі потовщені, а на вільних кінцях тонкі й заходять один за одного. 


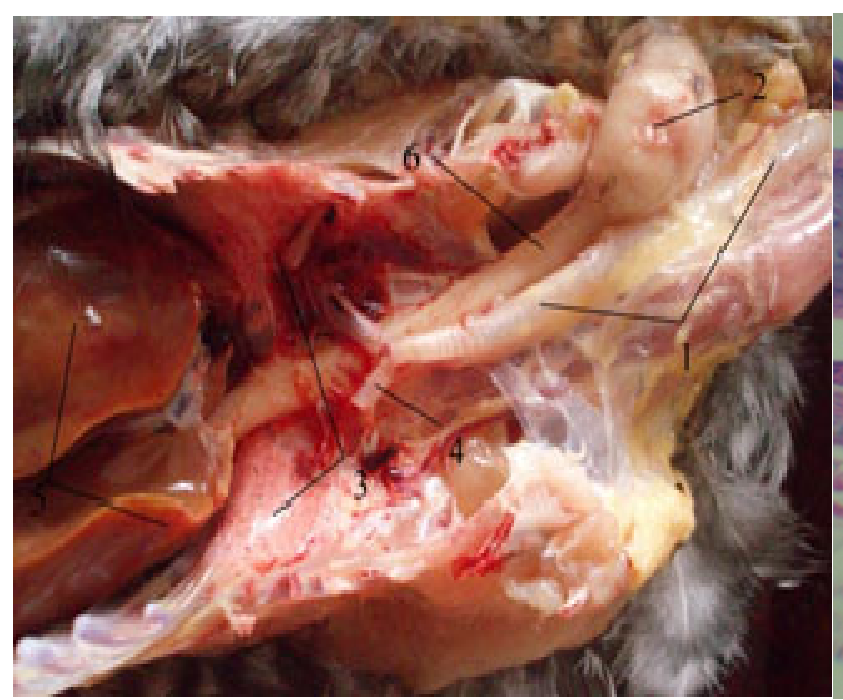

Рис. 1. Топографія трахеї курей: 180-добового віку: 1- трахея; 2 - воло; 3- легені; 4 - біфуркація трахеї; 5 - печінка; 6 - стравохід

Гістологічно стінка трахеї побудована з трьох оболонок: слизової, волокнисто-хрящової та адвентиції, які на поперечному зрізі чітко відмежовані одна від одної (рис. 2).

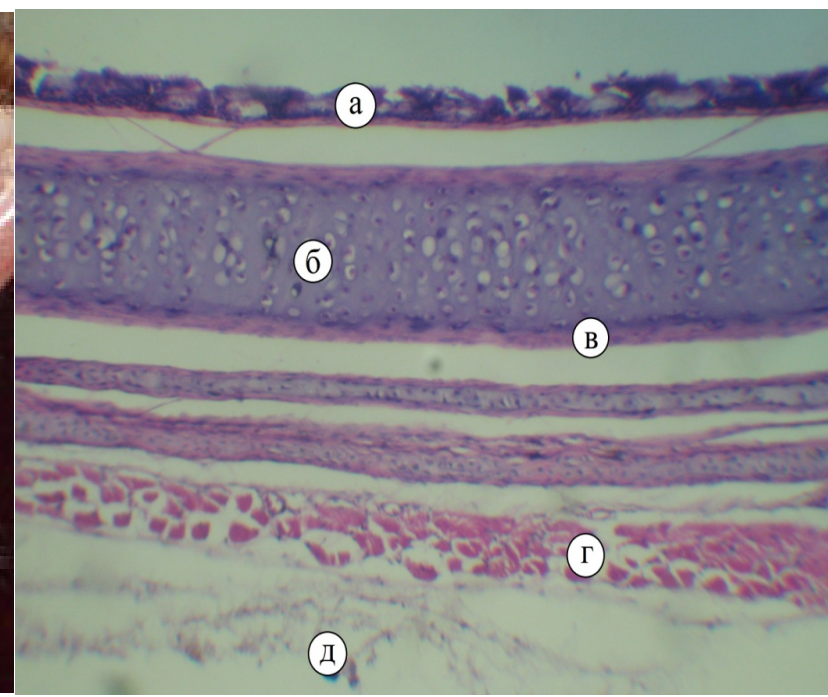

Рис. 2. Гістоструктура трахеї курей 180 -добового віку: а - одношаровий багаторядний миготливий епітелій; б - гіаліновий хрящ; в - охрястя, г - пучки гладких міоцитів, д - адвентиція. Гематоксилін

Караці та еозин. $\times 56$

Трахея у курей 180-добового віку дослідної групи має таке саме анатомо-топографічне розташування, як і у курей аналогічного віку контрольної групи тварин (табл. 1, рис. 1).

\section{Таблиця 1}

Органометричні показники трахеї курей контрольної та дослідної групи $(\mathrm{M} \pm \mathrm{m}, \mathrm{n}=10)$

\begin{tabular}{cccc}
\hline \multicolumn{2}{c}{ Довжина трахеї, мм } & \multicolumn{2}{c}{ Ширина трахеї, мм } \\
\hline контроль & дослід & контроль & дослід \\
$147,5 \pm 4,497$ & $152,66 \pm 5,84$ & $8,666 \pm 0,231$ & $8,0 \pm 0,282$ \\
\hline
\end{tabular}

Примітка: ${ }^{*}-\mathrm{P} \leq 0,05, * *-\mathrm{P} \leq 0,01, * * *-\mathrm{P} \leq 0,001$ (щодо контрольної групи)

Гістоархітектоніка органа подібна до такої у курей, вирощених в умовно чистій щодо радіоактивного забруднення зоні. Проте нашими морфометричними дослідженнями виявлено, що в курей відповідного віку дослідної групи збільшуються розміри кінцевих відділів трахейних залоз, потовщуються сполучнотканинні капсули лімфатичних вузликів. Абсолютна маса органа порівняно 3 контрольною групою має тенденцію до зменшення і становить $2,96 \pm 0,19$ г, тимчасом як відносна маса органа достовірно (Р $\leq 0,001)$ зменшується і становить $0,284 \pm 0,027 \%$.
Зміни відбуваються й у морфометричних показниках товщини оболонок органа. Так, згідно 3 морфометричними дослідженнями встановлено достовірне зменшення показників слизової, волокнисто-хрящової оболонок та адвентиції порівняно з курми, вирощеними в умовно чистій зоні. При цьому, товщина слизової оболонки у курей дослідної групи становить $31,85 \pm 0,705$ мкм, волокнисто-хрящової 188,37 \pm 3,23 мкм, адвентиції 133,77 $\pm 3,23$ мкм (табл. 2, рис. 3; 4).

\section{Таблиця 2}

Морфометричні показники трахеї курей контрольної та дослідної групи (M \pm m, n = 10)

\begin{tabular}{cccccc}
\hline \multirow{2}{*}{ Вік курей, діб } & \multicolumn{5}{c}{ Товщина оболонок трахеї, мкм } \\
\cline { 2 - 6 } & \multicolumn{2}{c}{ слизова } & волокнисто-хрящова & адвентиція \\
\cline { 2 - 6 } & контроль & дослід & контроль & дослід & контроль \\
\hline 180 & $47,6 \pm 1,86$ & $31,85 \pm 0,705 * * *$ & $214,76 \pm 5,77$ & $188,37 \pm 3,23 * *$ & $151,06 \pm 2,54$ \\
\hline
\end{tabular}

Примітка: *-P $\leq 0,05, * *-\mathrm{P} \leq 0,01, * * *-\mathrm{P} \leq 0,001$ (відносно контрольної групи) 


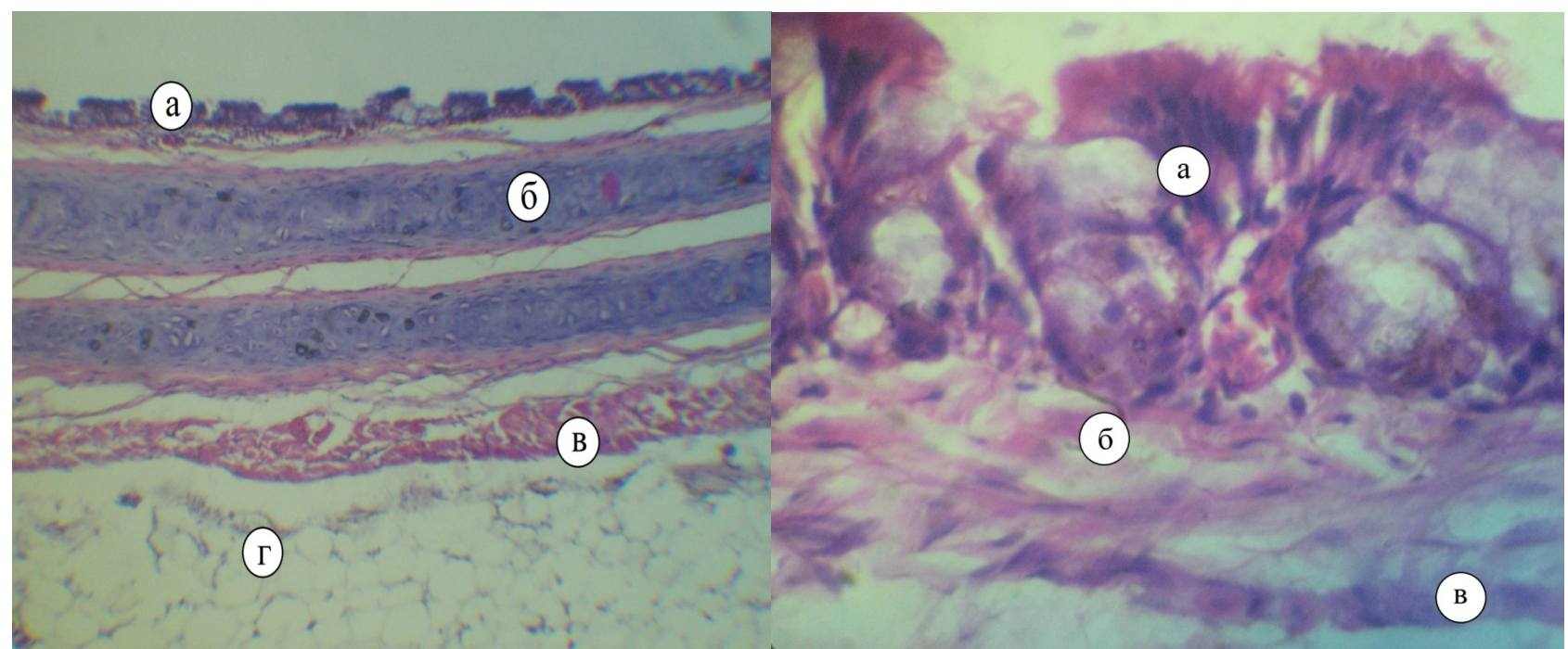

Рис. 3. Гістоструктура трахеї курей 180 -добового віку дослідної групи: а - слизова оболонка; б - волокнистохрящова оболонка; в - пучки гладких міоцитів; г - адвентиція. Гематоксилін Караці та еозин. ×56

\section{Висновки}

Згідно з радіологічними дослідженнями, у II зоні радіоактивного опромінення середня потужність експозиційної дози гамма-випромінювання втричі перевищувала цей показник в умовно чистій зоні. При цьому питома активність кормів раціону курей 180добового віку дослідної групи за цезієм-137 становила 13,4-16,0 Бк/кг, що достовірно у 8-9 разів більше порівняно 3 контролем (1,64-1,82 Бк/кг). Питома активність за цезієм-137 трахеї курей 180-добового віку була вищою на 5\% (13,8 $\pm 0,13$ Бк/кг) за аналогічний показник у курей контрольної групи $(13,1 \pm 0,1$ Бк/кг), що вказує на кумулятивну здатність цього ізотопу. Тривала дія малих доз іонізуючого випромінювання негативно впливає на морфофункціональний стан трахеї у курей дослідних груп, що проявляється кількісними змінами їх гістоструктури: зменшенням товщини слизової, волокнисто-хрящової та адвентиційної оболонок.

Перспективи подальших досліджень. В подальшому планується проведення ультрамікроскопічного дослідження органів дихання, в тому числі і трахеї у курей, вирощених в умовах радіоактивного забруднення.

\section{References}

Antoniuk, S.V., Kotsarev, O.S., \& Lykholat, O.A. (2002). Patomorfolohichni zminy lehen za umov tryvaloi dii nyzkykh doz oprominennia. Ukrainskyi radiolohichnyi zhurnal, 10, 249-253 (in Ukrainian).

Dieltsova, O.I., Herashchenko, S.B., \& Orishko, Ya.A. (1998). Struktura vnutrishnikh orhaniv v umovakh dovhotryvaloi dii malykh doz radiatsii. Materialy IIho Nats. konhresu anatomiv, histolohiv, embriolohiv i
Рис. 4. Гістоструктура слизової оболонки трахеї курей 180-добового віку дослідної групи: а - багаторядний миготливий циліндричний епітелій; б - власна пластинка; в - підслизова основа. Гематоксилін Караці та еозин $\times 400$

topohrafo-anatomiv (AHET) Ukrainy. Luhansk, 8485 (in Ukrainian).

Dubovyi, A.A. (2014). Histolohichna kharakterystyka ta morfometrychni pokaznyky shchytopodibnoi zalozy sobak, vyroshchenykh $\mathrm{v}$ umovakh radioaktyvnoho zabrudnennia. Visnyk Zhytomyr. nats. ahroekol. untu, 1(1), 119-125. http://nbuv.gov.ua/UJRN/ Vzhnau 2014 1\%281\%29 22 (in Ukrainian).

Dunaievska, O.F. (2013). Radiatsiina bezpeka urbolandshaftiv yak neobkhidna umova rozvytku turyzmu. Naukovi chytannia - 2013: nauk.-teoret. zb. Zhytomyr. nats. ahroekol. un-t. Zhytomyr: ZhNAEU, 1, 65-66. http://ir.znau.edu.ua/handle/123456789/869 (in Ukrainian).

Horalskyi, L.P., Fasolia, V.P., \& Dunaievska, O.F. (2004). Histoarkhitektonika orhaniv i tkanyn sobak, shcho utrymuvalys na radioaktyvno zabrudnenii terytorii. Visnyk DAU, 2(13), 75-76 (in Ukrainian).

Horalskyi, L.P., Khomych, V.T., \& Kononskyi, O.I. (2015). Osnovy histolohichnoi tekhniky i morfofunktsionalni metody doslidzhennia u normi ta pry patolohii: navch. Posibnyk. Zhytomyr: Polissia (in Ukrainian).

Horalskyi, L.P., Levchuk, O.K., Troianchuk, O.V., \& Hatskivskyi, V.V. (2012). Morfolohiia deiakykh orhaniv i tkanyn kurei, vyroshchenykh $\mathrm{v}$ umovno chystii ta 2-y zoni shchodo radioaktyvnoho zabrudnennia. Zootekhnichna nauka: istoriia, problemy, perspektyvy: materialy II mizhnar. nauk.-prakt. konf. Kamianets-Podilskyi, 289-290 (in Ukrainian).

Hudkov, I.M., \& Kashparov, V.O. (2012). Aktualni zavdannia i problemy silskohospodarskoi radioekolohii cherez chvert stolittia pislia avarii na Chornobylskii AES. Visnyk Zhytomyr. nats. ahroekol. un-tu, 1(1), 2736. http://ir.znau.edu.ua/handle/123456789/52 (in Ukrainian) 
Khomenko, Z.V. (2008). Zminy u histolohichnii budovi nyrky sobak pid Vplyvom malointensyvnoho ionizuiuchoho vyprominiuvannia. Naukovyi visnyk Lvivskoho natsionalnoho universytetu veterynarnoi medytsyny ta biotekhnolohii imeni S.Z. Hzhytskoho, 10, 3(38), 232-233. https://cyberleninka.ru/article/ v/zmini-u-gistologichniy-budovi-nirki-sobak-pidvplivom-malointensivnogo-ionizuyuchogoviprominyuvannya (in Ukrainian).

Kvacheva, Ju.E. (2002). Morfologicheskie tipy radiacionno-inducirovannoj gibeli kletok krovetvornoj tkani, ejo biologicheskaja sut' i znachimost' na razlichnyh jetapah razvitija ostrogo radiacionnogo porazhenija. Radiobiologija. Radiojekologija, 3, 287-292 (in Russian).

Lypska, A.I., Nikolaiev, V.I., Shytiuk, V.A., \& Kulich, N.V. (2014). Suchasnyi stan tekhnohennykh radionuklidiv v blyzhnii zoni ChAES. Radioekolohiia -
2014: zb. materialiv nauk.-prakt. konf. z mizhnar. uchastiu (m. Kyiv, 24-26 kvit. 2014 r.). Zhytomyr: Vyd-vo ZhDU im. I. Franka, 166-169 (in Ukrainian).

Romanchuk, L.D. (2012). Otsinka radiatsiinoho stanu hruntiv u pivnichnykh raionakh Zhytomyrshchyny, postrazhdalykh unaslidok avarii na ChAES. Visnyk ahrar. nauky, 6, 67-69 (in Ukrainian).

Troianchuk, O.V. (2012). Morfometrychni pokaznyky dvanadtsiatypaloi ta slipoi kyshok kurei u postnatalnomu periodi ontohenezu, vyroshchenykh v umovakh dii radioaktyvnoho zabrudnennia. Visnyk ZhNAEU, 2(33), 2, 153-158 (in Ukrainian).

Tykhenko, R.V. (2012). Suchasnyi stan ta problemy orhanizatsii radiatsiino zabrudnenykh terytorii na mistsevomu rivni. Visnyk Zhytomyr. nats. ahroekol. un-tu, 1(1), 203-209. http://ir.znau.edu.ua/bitstream/ 123456789/157/1/Tyhenko_R_Current_status_and_pr oblems_of_radiation.pdf(in Ukrainian). 